\title{
RASSF5 Gene
}

National Cancer Institute

\section{Source}

National Cancer Institute. RASSF5 Gene. NCI Thesaurus. Code C104719.

This gene plays a role in both lymphocyte adhesion and suppression of cell growth. 